\section{Measuring health inequalities: implications of choosing different socioeconomic indicators}

\author{
Aferição das desigualdades em saúde: as \\ implicações da escolha entre diferentes \\ indicadores socioeconômicos
}

\section{Midiendo inequidades de salud: implicaciones de elegir diferentes indicadores socioeconómicos}

Maria Laura Braccini Fagundes 1 Orlando Luiz do Amaral Júnior 1 Gabriele Rissotto Menegazzo ${ }^{1}$ Fernando Neves Hugo 2 Jessye Melgarejo do Amaral Giordani 1

\begin{abstract}
We aimed to verify the association between different socioeconomic indicators and self-rated health in a nationally representative sample of older adults. This cross-sectional study analyzed the baseline data from the Brazilian Longitudinal Study of Aging (ELSI-Brazil), a population-based cohort study of persons aged 50 years or older. Data was collected using a household and an individual questionnaire at participants' households. Self-rated health was assessed by a global self-rating item. Three socioeconomic indicators were assessed: individual income, per capita household income, and wealth index. Poisson regression models were performed to estimate the prevalence ratio $(P R)$ and $95 \%$ confidence intervals $(95 \% \mathrm{CI})$ of self-rated health and each socioeconomic indicator, adjusting for covariates. In total, 9,390 older adults answered the outcome question. Whilst for the individual income indicator only the richest quintile showed a statistically significant association with the outcome (PR: 0.90; 95\%CI: 0.87; 0.93), for the per capita household income, the fourth (PR: 0.95; 95\%CI: 0.91; 0.98) and the fifth quintiles (PR: 0.90; 95\%CI: 0.86; 0.94) remained associated with the outcome. Regarding the wealth index, only the second quintile was not associated with the outcome, with lower prevalence of poor self-rated health as richer was the quintile, showing a social gradient. The wealth index seems to be a more adequate indicator, as it reflects resources accumulated over the life course.
\end{abstract}

Health Surveys; Research Design; Social Determinants of Health; Socioeconomic Factors

\author{
Correspondence \\ M. L. B. Fagundes \\ Programa de Pós-graduação em Ciências Odontológicas, \\ Universidade Federal de Santa Maria. \\ Av. Roraima 1000, prédio 26F, Santa Maria, RS \\ 97105-900, Brasil. \\ mlaubf@gmail.com \\ 1 Programa de Pós-graduação em Ciências Odontológicas, \\ Universidade Federal de Santa Maria, Santa Maria, Brasil. \\ 2 Departamento de Odontologia Preventiva e Social, \\ Universidade Federal do Rio Grande do Sul, Porto Alegre, Brasil.
}




\section{Introduction}

Health surveys are the most common and useful type of study used to assess public health policies aimed at improving equity, which require the measurement and interpretation of health inequalities 1. The literature on this topic examines the distribution of health by different socioeconomic position, investigating the degree to which persons at lower socioeconomic position are more likely to present worse health outcomes 2 . These unfair differences are more prominent in most low- and middle-income countries, where life expectancy has increased much faster than in high-income ones 3. Although health declines in later life are expected, disability and disease prevalence in older adults are not equally distributed across social groups and those from higher socioeconomic position often experience better health 4 .

Health disparities by income, wealth, and social background are evident in Brazil among older adults 5. Self-rated health, in its turn, is one of the most common indicators used in social epidemiology and gerontology research, because it consistently predicts functional decline and mortality, and it might be the most feasible, most inclusive, and most informative measure of health status ${ }^{6}$. Moreover, individual's interpretation of their own health comprises an integrated perception including biological, psychosocial, and social dimensions, being strongly influenced by socioeconomic factors 7 . This association has been already demonstrated in previous studies with older adults in Brazil 8 .

Several socioeconomic indicators have been used to explore health inequalities, including individual income, household income per capita, and wealth index analyzed by ownership of durable goods and household characteristics 1,9. Regarding the statistical analyses, an indicator should be easy to collect during surveys, should not have volatile characteristics and should be comparable over place and time, which is not easy to fulfill in a single measure 1. Besides that, the choice for the most adequate socioeconomic position measure is relevant to make appropriate inferences, then, it should also consider different stages in the life course 10 . When assessing older adults socioeconomic position, the meaning of current income may be less sensitive and a less reliable indicator of their true socioeconomic position because the income typically reduces with age as older adults retire 10 . Therefore, it is reasonable to assume that the adoption of asset-based indicators could be a more adequate measure to be used in older adults' health research.

Thus, elucidating the explanatory potential of different socioeconomic position indicators might be useful to epidemiological research which seek to explore health inequalities in older adult populations and opportunities for their reduction, especially in developing countries. This study aimed to verify the association between different socioeconomic indicators (individual income, household income per capita, and wealth index) and self-rated health in a nationally representative sample of community-dwelling Brazilian older adults. We hypothesized that the wealth index is more appropriate for distinguishing health inequalities in older adults than individual or household income per capita indicators.

\section{Methods}

\section{Study design}

This cross-sectional study analyzed the baseline data from the Brazilian Longitudinal Study of Aging (ELSI-Brazil), a nationally representative population-based cohort study of persons aged 50 years or older. The baseline was conducted between 2015 and 2016 in 70 randomly selected municipalities, distributed in 21 states throughout Brazil.

\section{Ethics}

The study was approved by the Brazilian National Research Ethics Committee (CAAE: 63725117.9.0000.5091). A written informed consent form was obtained from every person that participated in the survey. 


\section{Sample}

The ELSI-Brazil sample procedure comprised selection stages, combining stratification of primary sampling units (municipalities), census tracts, and households. The sample was divided into four strata, with the first stratum drawn from 4,420 municipalities constituting $\leq 26,700$ inhabitants, the second from 951 municipalities constituting 26,701-135,000 inhabitants, third from 171 municipalities constituting 135,000-750,000 inhabitants, and fourth from 23 municipalities constituting $>750,000$ inhabitants. The sample for the first three strata (municipalities up to 750,000 inhabitants) was selected in three stages. In the first stage, 18 municipalities were selected in the first stratum, 15 in the second, and 14 in the third. In the second stage, eight census tracts were selected from each municipality, while households were selected from each census tract in the third stage. The sample for the fourth stratum - which included the largest municipalities - was selected in two stages, with 176 census tracts selected in the first stage and households selected in the second stage. All residents in the selected households that were aged 50 years and over and were invited to participate in the study.

The planned number of interviews considered an estimated prevalence of $1 \%$ (with a sample error of $0.25 \%$ ) or a prevalence of $5 \%$ (with a sample error of $0.55 \%$ ), with $95 \%$ confidence level, a 1.5 sample design effect and $80 \%$ sample power. The ELSI-Brazil final sample comprised 9,412 individuals.

\section{Data collection}

Data was collected using a household and an individual questionnaire by face-to-face interviews with previously trained interviewers at the participants' households. Further information is published elsewhere 11.

\section{Outcome}

Self-rated health was assessed by the question "In general, how do you rate your health?", later categorized into good (very good, good) or poor (regular, bad, very bad) 12 .

\section{Exposure variables}

The definitions of each socioeconomic indicator and the respective inequality measures are presented in Box 1. Three frequently used socioeconomic indicators were assessed: individual income, household income per capita and wealth index. Individual income was obtained asking the amount of Brazilian Reais (approximately USD 4 during the data gathering) received monthly. Household income per capita resulted from the total monthly gross household income divided by the number of residents. Wealth index was carried out using principal component analysis, a data reduction technique that produces a single continuous composite score from all the variables that retains as much variance as possible 13. It transforms a set of original variables to generate one summary measure of household wealth 14. Information on the ownership of durable goods was used: ownership of internet, washing machine, computer, landline, microwave, car. The highest scores for the generation of the wealth index were given by the variables "having access to internet at home" and "having a computer". All three indicators were categorized into quintiles, from the poorest to the richest, widely used in literature 1,15, to allow a proper comparison between the indicators and with other studies.

The conceptual theoretical model proposed by the Commission on Social Determinants of Health (CSDH) of the World Health Organization (WHO) was used to select possible covariates 16. Demographic, socioeconomic, behavioral, psychological and health variables were selected. Demographic and socioeconomic variables included sex (male, female), age group in years (50-59, 60-69, 70-79, 80 and older), skin color (categorized into white or non-white due to the low prevalence of non-white respondents), and education (categorized into 0 to 8 years, characterizing elementary education in Brazil, or 9 years or more). 
Box 1

Definitions of the socioeconomic variables and inequality measures used.

\begin{tabular}{|c|c|}
\hline SOCIOECONOMIC VARIABLES & DEFINITION \\
\hline Individual income & $\begin{array}{l}\text { It was obtained asking the amount of Brazilian Reais (approximately USD } 4 \text { during the data } \\
\text { gathering) received monthly. }\end{array}$ \\
\hline Household income per capita & $\begin{array}{l}\text { It resulted from the total monthly gross household income divided by the } \\
\text { number of residents. }\end{array}$ \\
\hline Wealth index & $\begin{array}{l}\text { It was created using principal components analysis, which transforms a set of original variables to } \\
\text { generate one summary measure of household wealth based on a list of household possessions } \\
\text { (television, refrigerator, etc.) and characteristics of the house (building materials, electricity, etc.). }\end{array}$ \\
\hline INEQUALITY MEASURE & DEFINITION \\
\hline Q5-Q1 & $\begin{array}{l}\text { Absolute measure of inequality based on the difference between the top and } \\
\text { bottom quintiles. If the outcome is more concentrated towards the poorest groups, } \\
\text { the measure assumes a negative value. }\end{array}$ \\
\hline Q5/Q1 & $\begin{array}{c}\text { Relative measure of inequality based on the ratio between the top and bottom quintiles. If the } \\
\text { outcome is more concentrated towards the poorest groups, the measure assumes } \\
\text { a negative value. }\end{array}$ \\
\hline Slope index of inequality (SII) & $\begin{array}{l}\text { This index is derived using linear regression of the health outcome on the midpoints of the ranks } \\
\text { obtained by ordering the sample by the explanatory variable. The SII is the slope of the resulting } \\
\text { regression line, and represents the absolute difference in the fitted value of the health indicator } \\
\text { between the highest (score of 1) and the lowest (score of } 0 \text { ) values of the socioeconomic indicator } \\
\text { rank. If the outcome is more concentrated towards the poorest groups, the index assumes a } \\
\text { negative value. }\end{array}$ \\
\hline Concentration index (CIX) & $\begin{array}{l}\text { The CIX uses an approach analogous to the Gini index by ranking individuals according to } \\
\text { socioeconomic position on the x-axis and plotting cumulative outcome on the y-axis. If the } \\
\text { outcome is more concentrated towards the poorest groups, the index assumes a negative value. }\end{array}$ \\
\hline
\end{tabular}

Source: prepared by the authors.

Smoking habit was deemed present if participants referred to smoke daily or less than daily. Medical attendance in the year prior to the study was assessed by the question: "In the last 12 months, how many times did you seek a physician?", categorized in yes (if one seek for at least one time) or no. The practice of moderate physical activity was deemed present if participants did some form of exercise continuously for at least 10 minutes at a given time. The individuals informed the frequency (days per week) and duration (time per day) of activities conducted in the week before the interview, which were converted into total physical activity time in the reported week. Regular practice was defined as practicing moderate activities at least 150 minutes per week, as recommended by the WHO 17.

To assess life satisfaction, the participants were instructed to think about their level of satisfaction with life and point to a step with numbers ranging from 1 to 10, with the highest step corresponding to the number 10 (representing the maximum satisfaction with life), whereas the lowest step was number 1 (representing the lowest satisfaction). The values were later dichotomized as low (steps from 1 to 5) or high (steps from 6 to 10). Depression was assessed by the question "Has any physician ever said that you have depression?” (yes/no). The number of chronic diseases was assessed questioning the participants if they had ever had a medical diagnostic of one of the following conditions: hypertension, diabetes, heart disease (heart attack, angina, or heart failure), stroke, asthma, chronic obstructive pulmonary disease, arthritis, cancer, or chronic kidney failure. Answers were categorized into none, one, or more than one disease. 


\section{Statistical analysis}

Data analyses were performed with the software Stata 14.0 (https://www.stata.com). All analyses incorporated sampling weights considering the complex sample using survey commands (svy). Initially, descriptive analyses were performed. Associations with the outcome were performed using Poisson regression models with robust variance, adjusting for possible covariates, with estimation of the crude and adjusted prevalence ratios (PR) and respective 95\% confidence intervals (95\%CI). Self-rated health was first adjusted for demographic and socioeconomic factors in Model 1 and was later adjusted for health behaviors, psychosocial factors and general health variables in Model 2. Analyses for each socioeconomic indicator were performed separately. The significance level was set at $5 \%(\mathrm{p}<0.05)$.

We also analyzed absolute and relative measures of inequality for each indicator, which represent the magnitude of inequality regarding socioeconomic measures 1 . As simple measures we included the observable absolute differences, in percentage points (p.p.), between the extreme wealth quintiles (the richest quintile and the poorest one Q5-Q1) and the ratio between them (Q5/Q1). As complex measures we included the slope index of inequality (SII) as indicator of absolute inequality and the relative concentration index (CIX). The SII is derived by linear regression of the health outcome on the midpoints of the ranks obtained by ordering the sample by the explanatory variable 18 . The CIX ranks individuals according to socioeconomic position on the $\mathrm{x}$-axis and plots the cumulative outcome on the y-axis, showing if the outcome is more concentrated towards the richer group 18.

\section{Results}

In total, 9,390 older adults answered the outcome question. Table 1 describes the prevalence of poor self-rated health according to demographic and socioeconomic characteristics, health behavior, psychosocial factors, and general health variables. Most respondents were females (53.4\%), self-declared as non-whites (57.2\%) and were aged between 50 to 59 years (47.6\%). Regarding health behaviors, 83.2\% have visited the doctor at least one time in the 12 months prior to the study, and $60.9 \%$ referred to practice moderate physical activities in a regular basis. The proportion of poor self-rated health was higher among those who self-declared as non-white, with less years of formal education, with lower life satisfaction and higher number of chronic diseases.

Table 2 shows sample distribution and prevalence of self-rated health according to the socioeconomic indicators and their respective inequality measures. Regarding the absolute inequality measures, the wealth index showed the highest absolute inequality (-27.7 p.p.), followed by the household income per capita (-25.2 p.p.) and the individual income (-18.9 p.p.). Regarding the complex inequality measures, the household income per capita and the wealth index showed similar values, with overlapping confidence intervals: SII: -28.7 (95\%CI: -32.2; -25.3) and CIX: -28.4 (95\%CI: -32.0; -24.8); SII: -28.4 (95\%CI: -31.9; -24.9) and CIX: -27.4 (95\%CI: -31.0; -23.7), respectively. Negative values suggest that the outcome is more prevalent in the most disadvantaged groups (the poorest) 19.

Table 3 shows the Poisson regression models assessing the association between each socioeconomic indicator and self-rated health. Whilst for the individual income indicator only the richest quintile showed a statistically significant association with the outcome (PR: 0.90; 95\%CI: 0.87; 0.93), for the household income per capita, the fourth (PR: 0.95; 95\%CI: 0.91; 0.98) and the fifth quintiles (PR: 0.90; 95\%CI: 0.86; 0.94) remained associated with the outcome. For the wealth index, only the second quintile was not associated with the outcome, with lower prevalence of poor self-rated health as richer was the quintile, showing a social gradient. 
Table 1

Characteristics of the sample and proportion of poor self-rated health according to exposure variables.

\begin{tabular}{|c|c|c|}
\hline Characteristics & $\begin{array}{l}\text { Weighted } \\
\% *\end{array}$ & $\begin{array}{l}\text { Poor self-rated health } \\
\quad \%(95 \% \mathrm{Cl}) *\end{array}$ \\
\hline \multicolumn{3}{|l|}{ Sex } \\
\hline Female & 53.9 & $56.1(53.6 ; 58.6)$ \\
\hline Male & 46.0 & $56.4(53.1 ; 59.6)$ \\
\hline \multicolumn{3}{|l|}{ Age (years) } \\
\hline $50-59$ & 47.6 & $55.3(52.0 ; 58.5)$ \\
\hline $60-69$ & 29.6 & $57.0(53.7 ; 60.3)$ \\
\hline $70-79$ & 15.6 & $58.6(55.5 ; 61.7)$ \\
\hline $80+$ & 7.0 & $54.0(49.8 ; 58.2)$ \\
\hline \multicolumn{3}{|l|}{ Skin color } \\
\hline White & 42.7 & $50.9(47.5 ; 54.3)$ \\
\hline Non-white & 57.2 & $60.1(57.9 ; 62.3)$ \\
\hline \multicolumn{3}{|c|}{ Formal education (years) } \\
\hline$\leq 8$ & 73.1 & $62.0(59.4 ; 64.5)$ \\
\hline$>8$ & 26.9 & $40.4(37.5 ; 43.5)$ \\
\hline \multicolumn{3}{|l|}{ Smoking habit } \\
\hline No & 84.3 & $56.4(53.8 ; 58.9)$ \\
\hline Yes & 15.7 & $55.6(52.3 ; 58.9)$ \\
\hline \multicolumn{3}{|c|}{ Medical attendance } \\
\hline Yes & 83.2 & $58.1(55.6 ; 60.7)$ \\
\hline No & 16.7 & $46.0(40.2 ; 49.9)$ \\
\hline \multicolumn{3}{|c|}{ Physical activity (minutes per week) } \\
\hline$\geq 150$ & 60.9 & $54.0(51.1 ; 56.8)$ \\
\hline$<150$ & 39.0 & $55.0(51.1 ; 58.8)$ \\
\hline \multicolumn{3}{|l|}{ Life satisfaction } \\
\hline Poor & 29.0 & $69.2(66.7 ; 71.6)$ \\
\hline Good & 70.9 & $49.9(46.8 ; 52.9)$ \\
\hline \multicolumn{3}{|l|}{ Depression } \\
\hline No & 81.8 & $56.6(54.0 ; 59.2)$ \\
\hline Yes & 18.1 & $54.8(51.9 ; 57.7)$ \\
\hline \multicolumn{3}{|l|}{ Chronic conditions } \\
\hline None & 29.1 & $38.5(35.3 ; 41.8)$ \\
\hline 1 & 34.7 & $55.4(52.8 ; 58.0)$ \\
\hline$>1$ & 36.0 & $70.8(68.1 ; 73.4)$ \\
\hline
\end{tabular}

95\% Cl: 95\% confidence interval.

* Considering the sample weight. 
Table 2

Characteristics of the sample, proportion of self-rated health according to socioeconomic indicators and respective absolute and relative inequality measures.

\begin{tabular}{|c|c|c|}
\hline Socioeconomic indicator & $\begin{array}{l}\text { Weighted } \\
\% *\end{array}$ & $\begin{array}{c}\text { Poor self-rated health } \\
\quad \%(95 \% \mathrm{Cl}) *\end{array}$ \\
\hline \multicolumn{3}{|l|}{ Individual income } \\
\hline Q1 (poorest) & 23.0 & $59.3(55.5 ; 63.0)$ \\
\hline Q2 & 22.4 & $64.2(61.8 ; 66.4)$ \\
\hline Q3 & 13.4 & $63.4(61.0 ; 65.7)$ \\
\hline Q4 & 19.8 & $55.9(52.8 ; 58.9)$ \\
\hline Q5 (richest) & 21.2 & $40.4(36.9 ; 44.0)$ \\
\hline Q5-Q1 (p.p.) & & -18.9 \\
\hline Q5/Q1 & & 0.68 \\
\hline SII (p.p.) & & $-23.4(-26.9 ;-19.8)$ \\
\hline $\mathrm{CIX}$ & & $-21.8(-25.5 ;-18.2)$ \\
\hline \multicolumn{3}{|l|}{ Household income per capita } \\
\hline Q1 (poorest) & 19.5 & $64.9(61.8 ; 67.8)$ \\
\hline Q2 & 19.1 & $64.6(61.8 ; 67.2)$ \\
\hline Q3 & 19.3 & $60.0(56.7 ; 63.2)$ \\
\hline Q4 & 20.9 & $53.8(50.5 ; 57.0)$ \\
\hline Q5 (richest) & 21.0 & $39.7(36.6 ; 43.0)$ \\
\hline Q5-Q1 (p.p.) & & -25.2 \\
\hline Q5/Q1 & & 0.61 \\
\hline SII (p.p.) & & $-28.7(-32.2 ;-25.3)$ \\
\hline $\mathrm{CIX}$ & & $-28.4(-32.0 ;-24.8)$ \\
\hline \multicolumn{3}{|l|}{ Wealth index } \\
\hline Q1 (poorest) & 20.2 & $65.0(62.2 ; 67.7)$ \\
\hline Q2 & 22.3 & $64.6(61.8 ; 67.2)$ \\
\hline Q3 & 22.3 & $59.5(56.6 ; 62.3)$ \\
\hline Q4 & 18.9 & $51.1(47.5 ; 54.7)$ \\
\hline Q5 (richest) & 17.3 & $37.3(34.3 ; 40.5)$ \\
\hline Q5-Q1 (p.p.) & & -27.7 \\
\hline Q5/Q1 & & 0.57 \\
\hline SII (p.p.) & & $-28.4(-31.9 ;-24.9)$ \\
\hline $\mathrm{CIX}$ & & $-27.4(-31.0 ;-23.7)$ \\
\hline
\end{tabular}

95\%Cl: 95\% confidence interval; CIX: concentration index; p.p.: percentage points; Q: quintile; SII: slope index of inequality.

* Considering the sample weight. 
Table 3

Crude and adjusted associations between poor self-rated health and exposure variables determined through Poisson regression models.

\begin{tabular}{|c|c|c|c|}
\hline Socioeconomic indicators & $\begin{array}{c}\text { Crude } \\
\text { PR }(95 \% \mathrm{Cl}) *\end{array}$ & $\begin{array}{c}\text { Model } 1 \\
\text { PR }(95 \% \mathrm{Cl}) *\end{array}$ & $\begin{array}{c}\text { Model } 2 \\
\text { PR }(95 \% \mathrm{Cl}) *\end{array}$ \\
\hline \multicolumn{4}{|l|}{ Individual income } \\
\hline Q1 (poorest) & 1.00 & 1.00 & 1.00 \\
\hline Q2 & $1.03(1.00 ; 1.05)$ & $1.01(0.99 ; 1.04)$ & $0.98(0.95 ; 1.01)$ \\
\hline Q3 & $1.02(0.99 ; 1.05)$ & $1.01(0.98 ; 1.04)$ & $0.98(0.95 ; 1.01)$ \\
\hline Q4 & $0.97(0.95 ; 1.00)$ & $0.97(0.95 ; 1.00)$ & $0.97(0.94 ; 1.01)$ \\
\hline Q5 (richest) & $0.88(0.85 ; 0.90)$ & $0.90(0.87 ; 0.93)$ & $0.90(0.87 ; 0.93)$ \\
\hline \multicolumn{4}{|l|}{ Household income per capita } \\
\hline Q1 (poorest) & 1.00 & 1.00 & 1.00 \\
\hline Q2 & $0.99(0.97 ; 1.02)$ & $1.00(0.97 ; 1.02)$ & $1.00(0.96 ; 1.03)$ \\
\hline Q3 & $0.97(0.94 ; 0.99)$ & $0.97(0.95 ; 0.99)$ & $0.96(0.92 ; 1.01)$ \\
\hline Q4 & $0.93(0.90 ; 0.95)$ & $0.95(0.92 ; 0.97)$ & $0.95(0.91 ; 0.98)$ \\
\hline Q5 (richest) & $0.84(0.82 ; 0.86)$ & $0.88(0.86 ; 0.91)$ & $0.90(0.86 ; 0.94)$ \\
\hline \multicolumn{4}{|l|}{ Wealth index } \\
\hline Q1 (poorest) & 1.00 & 1.00 & 1.00 \\
\hline Q2 & $0.99(0.97 ; 1.02)$ & $1.00(0.97 ; 1.02)$ & $0.97(0.94 ; 1.00)$ \\
\hline Q3 & $0.96(0.94 ; 0.98)$ & $0.98(0.96 ; 1.00)$ & $0.95(0.92 ; 0.98)$ \\
\hline Q4 & $0.91(0.89 ; 0.94)$ & $0.94(0.92 ; 0.97)$ & $0.92(0.89 ; 0.95)$ \\
\hline Q5 (richest) & $0.83(0.80 ; 0.85)$ & $0.87(0.85 ; 0.90)$ & $0.87(0.84 ; 0.90)$ \\
\hline
\end{tabular}

95\%Cl: 95\% confidence interval; PR: prevalence ratio; Q: quintile.

Note: Model 1: adjusted for demographic and socioeconomic characteristics; Model 2: adjusted for demographic and socioeconomic characteristics, health behavior, psychosocial factors and general health variables.

* Considering the sample weight.

\section{Discussion}

Our findings suggest that when comparing the adoption of different indicators of socioeconomic position (individual income, household income per capita and wealth index) categorized in quintiles and its association with self-rated health of individuals aged 50 years or older, the wealth index seems to be more sensitive in identifying scenarios of socioeconomic inequalities related to self-rated health. Few studies evaluate socioeconomic indicators on health outcomes in developing countries 10,20. Therefore, these findings are pioneers in assessing which socioeconomic indicator is more adequate for identifying health disparities in countries facing inequalities, as Brazil. To understand statistical effect of different indicators is essential to plan and to interpretate relevant epidemiological studies to the scientific community as well as to the health strategy managers 20,21 .

Although efforts to collect asset information as part of collecting administrative data may be difficult, the explanatory power of alternative indicators of socioeconomic position based on wealth seems to have a better quality when compared to more conventional indicators ${ }^{9}$. Further, in lowincome countries can be more difficult to measure due to a greater dependence on informal economy, self-employment, and seasonal activities ${ }^{20}$. Depending on the environment, casual and seasonal work may be more common than formal employment, while multiple jobs and domestic businesses may prevail 20 . Note that, an individual can feel uncomfortable to say how much money they earned for several reasons, such as, theft or taxation and, consequently, generate incomplete information about income, while information about assets and goods tend to be more faithful as the survey nonresponse bias can be minimized 22 . 
When comparing the inequality measures for each indicator, the wealth index seems to show the greatest inequalities. There is no consensus on the ideal measure for expressing the magnitude of inequalities, but some limitations must be considered to interpret them. The simple measures (differences and ratios) are sensitive to changes in the number of individuals in each stratum, and the intermediate population groups will not be addressed 1 . In its turn, complex measures may overcome this limitation as they use information of the whole population 23 . The negative point of the CIX is the lack of direct interpretability of its values, while the simple ratios are easily interpretable 23 . It is almost a consensus that no single measure of inequality reveals the full picture, so both absolute and relative measures should be reported ${ }^{18}$. While relative measures provide an idea of the degree of unfairness, the absolute measures provide clues of the necessary effort to close the gap 1.

Individual income and household income per capita were associated with health only when income disparities are extreme, comparing the richest quintiles to the poorest ones. Thus, wealth index seems to better address the socioeconomic position of older adults. Therefore, unique income indicators may not reflect the financial resources available and disregard the accumulated value effects of a lifetime of deprivation or privilege 24 , besides the fact that family members may have unequal access to family income 9 . Notwithstanding, older adults frequently have little income as they are generally out of the workforce, but may have substantial wealth, since that to accumulate wealth demands a long time 9 . For public policy, when considering data collection and reporting, it is important to evaluate the relative utility of the chosen indicators for specific age groups, because the commonly used indications adopted to capture older adult's socioeconomic position 24 can present inadequacy.

Moreover, our findings for the older ages are relevant due to the fact that older people are more likely to live with chronic diseases and functional disabilities, which reduces their independence and autonomy. For this reason, older adults require longitudinal and constant care and, in the event of illness, demand longer hospital stays and greater palliative care, generating expenses with medications and health professionals 25. Furthermore, socioeconomic status has been recognized as a risk factor for morbidity and mortality 26 . Therefore, to reduce inequalities and to plan health policies that improve older adults' quality of life are a social responsibility, since that diseases negatively impact especially the poorest, disadvantaged and socially marginalized 27.

Some limitations must be considered when interpreting our findings. We highlight that no single measure will be ideal for all studies and contexts. Thus, the strengths and limitations of each indicator may vary depending on the specific population and research question. Furthermore, to allow comparability between socioeconomic indicators, as well as with other studies, we categorized them in quintiles. The division into quintiles needs to be interpreted carefully, as the asymmetric distribution of income generates homogeneous categories (many people with low income can result in little difference in income between the lower value categories). The use of a nationally representative sample of Brazilian older adults, as well as the high quality of the data collected are strengths of this study. ELSI-Brazil is part of an international network of longitudinal studies on aging adopting a robust methodology, making feasible to conduct similar studies in different countries and contexts. To the best of our knowledge, this is the first study comparing these distinct indicators and its link with older adults' self-rated health.

We can conclude that there are differences in the measurement of health inequalities depending on the socioeconomic indicator adopted. Especially for studies on older adults' populations, the wealth index seems to be a more adequate indicator to be used, when comparing to individual or household income per capita with same categorization. Moreover, it is essential that researchers clarify the different interpretations of these indicators to public health managers, as they may affect the approaches taken to reduce inequalities. 


\section{Contributors}

M. L. B. Fagundes, O. L. Amaral Júnior, and G. R. Menegazzo conceptualized and designed the study, executed the initial analyses, drafted the initial manuscript, revised the manuscript and approved the final manuscript. F. N. Hugo and J. M. A. Giordani conceptualized and designed the study, coordinated and supervised the initial manuscript, executed the analyses, critically reviewed the manuscript and approved the final manuscript.

\section{Additional informations}

ORCID: Maria Laura Braccini Fagundes (00000001-5548-7408); Orlando Luiz do Amaral Júnior (0000-0002-6611-3871); Gabriele Rissotto Menegazzo (0000-0002-4181-0267); Fernando Neves Hugo (0000-0003-2222-7719); Jessye Melgarejo do Amaral Giordani (0000-0002-3825-9734).

\section{References}

1. Barros AJD, Victora CG. Measuring coverage in $\mathrm{MNCH}$ : determining and interpreting inequalities in coverage of maternal, newborn, and child health interventions. PLoS Med 2013; 10:e1001390.

2. Wagstaff A, Watanabe N. What difference does the choice of SES make in health inequality measurement? Health Econ 2003; 12:885-90.

3. Palloni A, Pinto-Aguirre G, Pelaez M. Demographic and health conditions of ageing in Latin America and the Caribbean. Int J Epidemiol 2002; 31:762-71.

4. Lima-Costa MF, De Oliveira C, Macinko J, Marmot M. Socioeconomic inequalities in health in older adults in Brazil and England. Am J Public Health 2012; 102:1535-41.

5. Lima-Costa MF, Mambrini JVM, Peixoto SV, Malta DC, Macinko J. Socioeconomic inequalities in activities of daily living limitations and in the provision of informal and formal care for noninstitutionalized older Brazilians: $\mathrm{Na}$ tional Health Survey, 2013. Int J Equity Health 2016; $15: 137$

6. Jylhä M. What is self-rated health and why does it predict mortality? Towards a unified conceptual model. Soc Sci Med 2009; 69:307-16.

7. Moor I, Spallek J, Richter M. Explaining socioeconomic inequalities in self-rated health: a systematic review of the relative contribution of material, psychosocial and behavioural factors. J Epidemiol Community Health 2017; 71:565-75

8. Borim FSA, Neri AL, Francisco PMSB, Barros MBA. Dimensions of self-rated health in older adults. Rev Saúde Pública 2014; 48:714-22.

9. Duncan GJ, Daly MC, McDonough P, Williams DR. Optimal indicators of socioeconomic status for health research. Am J Public Health 2002; 92:1151-7.

10. Galobardes B. Indicators of socioeconomic position (part 1). J Epidemiol Community Health 2006; 60:7-12.

11. Lima-Costa MF, de Andrade FB, de Souza Jr. PRB, Neri AL, Duarte YAO, Castro-Costa E, et al. The Brazilian Longitudinal Study of Aging (ELSI-Brazil): objectives and design. Am J Epidemiol 2018; 187:1345-53.

12. Hakeberg M, Wide Boman U. Self-reported oral and general health in relation to socioeconomic position. BMC Public Health 2018; 18:63.

13. Jolliffe IT, Cadima J. Principal component analysis: a review and recent developments. Philos Trans A Math Phys Eng Sci 2016; 374:20150202.

14. Firestone R, Fry K, Chakraborty NM. Measuring equity with nationally representative wealth quintiles. Washington DC: Population Services International; 2014.

15. Andrade FB, Antunes JLF, Souza Junior PRB, Lima-Costa MF, Oliveira CD. Life course socioeconomic inequalities and oral health status in later life. Rev Saúde Pública 2019; 52 Suppl $2: 7 \mathrm{~s}$. 
16. World Health Organization. A conceptual framework for action on the social determinants of health: debates, policy \& practice, case studies. http://apps.who.int/iris/bitstre am/10665/44489/1/9789241500852_eng.pdf (accessed on 09/Apr/2020).

17. World Health Organization. Global recommendations on physical activity for health. Geneva: World Health Organization; 2010.

18. Wagstaff A, Paci P, van Doorslaer E. On the measurement of inequalities in health. Soc Sci Med 1991; 33:545-57.

19. Silva ICM, Restrepo-Mendez MC, Costa JC, Ewerling F, Hellwig F, Ferreira LZ, et al. Mensuração de desigualdades sociais em saúde: conceitos e abordagens metodológicas no contexto brasileiro. Epidemiol Serv Saúde 2018; 27:1-12.

20. Howe LD, Galobardes B, Matijasevich A, Gordon D, Johnston D, Onwujekwe O, et al. Measuring socio-economic position for epidemiological studies in low- and middle-income countries: a methods of measurement in epidemiology paper. Int J Epidemiol 2012; 41:871-86
21. Marmot M. The influence of income on health: views of an epidemiologist. Health Aff (Millwood) 2002; 21:31-46.

22. Moore JC, Stinson LL, Welniak EJ. Income measurement error in surveys: a review. J Off Stat 2000; 16:33-6.

23. Harper S, Lynch J. Methods for measuring cancer disparities: using data relevant to healthy people 2010 cancer-related objectives. Rockville: National Cancer Institute; 2005.

24. Robert S, House JS. SES differentials in health by age and alternative indicators of SES. J Aging Health 1996; 8:359-88.

25. Veras R, Oliveira M. Care pathway for the elderly: detailing the model. Rev Bras Geriatr Gerontol 2016; 19:887-905.

26. Berkman CS, Gurland BJ. The relationship among income, other socioeconomic indicators, and functional level in older persons. J Aging Health 1998; 10:81-98.

27. Barbosa KGN. Status of oral health in elderly: a review of Brazilian reality. Odontologia Clínico-Científica 2011; 10:227-31. 


\section{Resumo}

O estudo buscou verificar a associação entre diferentes indicadores socioeconômicos e autoavaliação da saúde em uma amostra nacionalmente representativa de adultos mais velhos. Este estudo transversal analisou os dados da linha de base do Estudo Longitudinal de Saúde dos Idosos Brasileiros (ELSI-Brasil), um estudo de coorte de base populacional em indivíduos com 50 anos ou mais. Os dados foram coletados através de um questionário domiciliar e individual no domicílio dos participantes. A autoavaliação da saúde foi avaliada com um item de autoavaliação global. Três indicadores socioeconômicos foram avaliados: renda individual, renda domiciliar per capita $e$ indice de riqueza. Foram construídos modelos de regressão Poisson para estimar a razão de prevalência $(R P)$ e os intervalos de $95 \%$ de confiança (IC95\%) para autoavaliação da saúde e cada indicador socioeconômico, ajustando para variáveis de confusão. No total, 9.390 idosos responderam à pergunta referente a autoavaliação de saúde geral. Para o indicador de renda individual, apenas o quintil mais rico mostrou uma associação significativa com o desfecho (RP: 0,90; IC95\%: 0,87; 0,93); enquanto isso, para a renda domiciliar per capita, o quarto (RP: 0,95; IC95\%: 0,91; 0,98) e quinto quintis (RP: 0,90; IC95\%: 0,86; 0,94) permaneceram associados com o desfecho. Com relação ao indice de riqueza, apenas o segundo quintil não esteve associado com o desfecho. As menores prevalências de autoavaliação ruim da saúde foram associadas aos quintis mais altos de riqueza, revelando um gradiente social. $O$ indice de riqueza parece ser um indicador mais adequado para uso, na medida em que reflete os recursos acumulados ao longo da vida.

Inquéritos Epidemiológicos; Projetos de Pesquisa; Determinantes Sociais da Saúde; Fatores

Socioeconômicos

\section{Resumen}

Nuestro objetivo fue verificar la asociación entre diferentes indicadores socioeconómicos y de salud autoevaluada en una muestra representativa nacional de adultos mayores. Este estudio transversal analizó los datos de referencia del Estudio Longitudinal de Salud de los Ancianos (ELSI-Brasil), un estudio de cohorte basado en población con individuos de 50 años o más. Los datos fueron recogidos usando un cuestionario por domicilio e individual entre los hogares participantes. La salud autoevaluada se evaluó mediante un item de autoevaluación global. Se evaluaron tres indicadores socioeconómicos: ingresos individuales, ingresos per cápita por hogar e indice de riqueza. Se realizaron modelos de regresión de Poisson para estimar la ratio de prevalencia $(R P)$ y los intervalos de 95\% de confianza (IC95\%) de salud autoevaluada y cada indicador socioeconómico, ajustándolos mediante variables de confusión. En total, 9.390 personas mayores respondieron la pregunta sobre la autoevaluación de la salud general. Mientras que para el indicador de ingresos individuales solamente el quintil más rico mostró una asociación estadísticamente significativa con el resultado ( $R P$ : 0.90; IC95\%: 0.87; 0.93), en los ingresos per cápita por hogar, los quintiles cuarto (RP: 0.95; IC95\%: $0.91 ; 0.98)$ y quinto (RP: 0.90; 95\%CI: 0.86; 0.94) continuaron asociados con el resultado. Respecto al indice de riqueza, solo el segundo quintil no estuvo asociado con el resultado, con prevalencia más baja de salud autoevaluada peor percibida cuanto más rico era el quintil, mostrando un gradiente social. El indice de riqueza parece ser un indicador más adecuado respecto a su uso, puesto que refleja fuentes acumuladas a lo largo del curso de la vida.

Encuestas Epidemiológicas; Proyectos de Investigación; Determinantes Sociales de la Salud; Factores Socioeconómicos
Submitted on $11 / \mathrm{Feb} / 2021$

Final version resubmitted on 16/Jun/2021

Approved on 02/Jul/2021 